\title{
Barriers to the Use of Information and Communication Technology (ICT) in Secondary Schools: Teacher's Perspective
}

\author{
Dr. Ch. V. V. S. N. V. Prasad (Corresponding author) \\ Dept. of Economics and Management, BITS Pilani \\ Goa Campus, Zuari Nagar, Goa, India \\ Tel: 91-832-258-0420Ｅ-mail: prasad@goa.bits-pillani.ac.in
}

\author{
Dr. P. Lalitha \\ Dept. of Economics, BITS Pilani \\ Hyderabad Campus, Hyderabad, India \\ Tel: 91-91-7738-4317Ｅ-mail: plalitha@hyderabad.bits-pilani.ac.in
}

\author{
Mr. P. V. N. Srikar \\ Dept. of Economics, BITS Pilani \\ Goa Campus, Zuari Nagar, Goa, India \\ Tel: 91-88-0685-7577Ｅ-mail: f2011497@goa.bits-pilani.ac.in
}

Received: August 27, 2014 Accepted: November 22, $2014 \quad$ Published: February 1, 2015

doi:10.5296/jmr.v7i2.6935 URL: http://dx.doi.org/10.5296/jmr.v7i2.6935

\begin{abstract}
This study investigates the teachers' perceptions of barriers to using Information and Communication Technology (ICT) in secondary schools in India. Even though the progress of ICT for teaching is growing, very few studies address ICT particularly regarding secondary schools in India. This study has reviewed the existing literature pertaining to ICT in secondary schools and has analyzed barrier factors in relation to secondary schools in India.
\end{abstract}




\section{Macrothink}

Journal of Management Research

ISSN 1941-899X

2015, Vol. 7, No. 2

A 10-item questionnaire was administered to 749 secondary school teachers in India. Results from the study shows that lack of funding, lack of ICT integration and lack of connectivity were found to be most critical barriers to the use of ICT in secondary schools. Three barrier-factors were extracted: lack of support, lack of ICT infrastructure and lack of motivation and self belief from factor analysis.

Keywords: Information and Communication Technology (ICT), Secondary Schools, ICT Barriers 


\section{Introduction}

Technology has steadily risen to become a critical tool in secondary education. However, despite its ability and significance in supporting the development of school children, school childhood educators have struggled with technology usage in their teaching practice. The arena of education though, has been certainly affected by the powerful and penetrating global influence of ICT. It has made a deep and significant impact on the qualitative and quantitative teaching aspects in educational institutions. ICT has the ability of inspiring and engaging the students in learning to link the school experiences to the work practices; improving, enriching and perpetuating skill; creating economic viability for future workers; providing transformative changes in schools; bolstering teaching and creating a window for strong connection between the school and the external world. Owing to the key function of education in influencing country growth and steady spurt in secondary school population, use of ICT in teaching practices has become very vital. Adoption of ICT techniques by teachers will enable them to teach more effectively and efficiently in such circumstances. State and central governments have recognized this aspect and have taken strong steps to improve ICT usage in secondary schools using the ICT in school scheme. Extant research has also identified and stressed on the critical advantages of providing young children with exposure to technology and integrating into their school curriculum (Castellani \& Jeffs, 2001). The integration of ICT in learning and teaching provides significant opportunities for students and teachers alike, to work progressively in today's information age. However, certain factors can impede teachers' ability to integrate and use ICT in their teaching practice (Salehi and Salehi, 2012). The relationship between usage and perceptions of ICT, organizational culture and ICT system implementation has been the focus of examination (Pliskin et.al. 1993). The use of ICT in secondary schools is influenced by school culture in terms ICT infrastructure support and teacher motivation and self beliefs of using ICT in their teaching or learning. By analyzing the barriers of using ICT in education, assistance can be provided to educators for overcoming these impediments. The study aims investigates the teachers' perceptions of barriers to the use of ICT in secondary schools in India.

\section{Review of Literature}

Research studies (Jones 2004; Al- Senaidi et al. 2009; Karasavvidis 2009; Agyei and Voogt 2011; Prestridge 2012) have reported a number of barriers/obstacles teachers experience in using ICT in their classrooms. These include lack of resource access, inadequate training opportunities, lack of confidence amongst among teachers, paucity of time, insufficient knowledge about integration of ICT in lessons, technical issues, poor administrative support and poor fit with the curriculum. Barriers must be first identified, and then only actions can be taken to overcome those (Nikolopoulou \& Gialamas 2013). Copley and Ziviani (2004) identified barriers such as inadequate staff training, negative staff attitudes towards ICT usage, dearth of funds, impediments in procuring and managing ICT equipment, insufficient planning and assessment processes and lack of time. Inadequate technical support toward ICT at schools and lack of required access to internet were also identified as major impediments to the integration of ICT into curriculum as stated by (Salehi \& Salehi 2012). Paucity of class time was also identified as another major barrier which discouraged teachers 
from using ICT in classrooms. McCarney (2004) reported that the inadequate number of computers, dearth of class time for students to use computers and insufficient free time for learning were the most significant barriers. Insufficient training and paucity of professional development programmes for integrating technology into the existing curriculum were also identified as major hindrances toward ICT integration in schools (Georgina \& Hosford, 2009; ChanLin, Hong, Horng, Chang \& Chu, 2006). Lack of class time was another factor that prevented teachers from using ICT in classrooms (Salehi \& Salehi, 2012). Wood et al. (2005) showed that confidence with technology was linked to better computer integration in the classroom. They identified individual characteristics such as experience with computers and confidence with technology as reasons for why teachers do not use computers (in spite of the increased availability of hardware). Paucity of software, lack of funds, inadequate time and lack of technical skills were also found to be the major barriers to the usage of technology in most Jordanian schools (Ihmeideh, 2009).

Some barriers such as limited resources, lack of time, lack of technical support are related to external to the teacher called external barriers, while others are such as teachers' negative attitudes and lack of confidence are related to teacher called internal barriers (Bingimlas 2009; Al- Senaidi et al. 2009). Researchers also refer to other ways of grouping the barriers such as school level barriers and teacher level barriers. Teacher level barriers relate to the teacher and school level barriers relate to the institution or school. (Veen 1993). Teacher level barriers includes teachers lack of motivation, teachers self belief of using ICT and lack of confidence in using ICT. School lever barriers can be further classified into two categories: one related to school ICT infrastructure and other related to technical and administrative support provided by the school. It was evident from the literature that barriers to the use of ICT in secondary school include lack of motivation (Ertmer, 1999; Ilomäki, 2011; Lo" fstro“m, \& Nevgi, 2008); lack of confidence (Richardson, 2011; Ertmer, 1999; Jones, 2004; Copley, and Ziviani, 2004); lack of funding (Saheli, \& Saheli, 2012; Ertmer, 1999; Nikolopoulou, \& Gialamas, 2013; Copley, and Ziviani, 2004; Han, 2008; Lim, \& Khine, 2006; Neyland, 2011; Oye et al., 2011); lack of skilled personnel (Richardson, 2011; Pelgrum, 2001; Ilomäki ,2011; Saheli, \& Saheli, 2012; M. M. Yunus, M. Lubis, and C. Lin 2009; Ihmeideh, 2009); poor ICT infrastructure (Richardson, 2011; Rodrigo, 2005; Pelgrum, 2001; Oye et al., 2011; Galanouli et al.,2004; Ihmeideh, 2009; Copley and Ziviani 2004; Butler \& Sellbom, 2002; Groves \& Zemel, 2000); low connectivity (Richardson, 2011; Rodrigo, 2005; Saheli, \& Saheli, 2012; Galanouli et al.,2004 ); lack of ICT integration (Rodrigo, 2005; Pelgrum ,2001); lack of awareness (Richardson, 2011; Jones,2004); inadequate maintenance of hardware and software (Richardson, 2011; Nikolopoulou, \& Gialamas, 2013; Bichelmeyer, \& Molenda, 2006; Copley and Ziviani 2004); and power interruptions (Richardson, 2011).

\section{Objectives and Methodology}

\subsection{Objectives of the Study}

The main purpose of this study was to investigate the barriers to the use of ICT in secondary schools. The study aimed to answer the following research questions.

1. To investigate secondary school teachers' perceptions with regard to barriers in using ICT 
in secondary schools;

2. To categorize the factor-level barriers that narrates to the use of ICT in secondary schools;

3. To analyze the influences of teachers' personal characteristics (gender, age, annual income and designation) on teachers' perceived barrier factors.

4. To analyze the influences of teachers' ICT usage characteristics (computer proficiency, computer experience, ownership of computer/laptop, internet connection at home and time spent on computers/internet) on teachers' perceived barrier factors.

\subsection{The Sample}

The sample consisted of 749 secondary school teachers selected from 100 schools representing following 4 states of India: Andhra Pradesh, Goa, Kerala and Tamilnadu. Table 1 shows the demographic profile of secondary school teachers (gender, age, designation and annual income).

Table 1. Demographic Profile of Teachers

\begin{tabular}{|l|c|c|}
\hline Gender & Frequency & Percentage (\%) \\
$\quad$ Male & 288 & 38.5 \\
Female & 461 & 61.5 \\
Age & & \\
$\quad<35$ years & 307 & 41.0 \\
35-50 years & 374 & 49.9 \\
$\quad>50$ years & 68 & 9.1 \\
Designation & & \\
$\quad$ Principal & 20 & 2.7 \\
teacher & 715 & 95.5 \\
Computer & 14 & 1.9 \\
Technician & & \\
Annual Income & & 46.6 \\
$\quad<$ Rs.200000 & 349 & 47.0 \\
Rs.200000-Rs.500 & 352 & 6.4 \\
000 & & \\
$>$ Rs.500000 & 48 & \\
\hline
\end{tabular}

\subsection{Research Instrument}

To fulfill the research objectives of this study, a comprehensive survey methodology using questionnaire was designed to capture the facts as well as qualitative responses about the barriers of using ICT in secondary schools. The questionnaire was administered in the 
academic year 2013-2014. Data was collected using questionnaire, which consists of two sections. Section A includes questions relating to teachers' personal characteristics (gender, age, annual income, and designation) and teachers ICT usage characteristics (computer proficiency, computer experience, ownership of computer/laptop, internet connection at home and time spent on computers/internet). Section B consists of 10 statements aiming to investigate teachers' perceived barriers to the adoption of ICT in secondary schools. The 10 statements were separated into three groups, as follows: the first group involved four statements related to lack of ICT support, the second group involved three statements related to lack of ICT infrastructure, and the third group involved three items related to lack of motivation and self belief. The respondents were required to indicate importance of each barrier on a 5 point Likert scale with 1 (one) as very less important barrier and 5(five) as very high important barrier. The questionnaire was administered to 749 secondary school teachers in India. Thorough literature review and pilot study was conducted to establish content validity for the questionnaire. Initially, a literature review was conducted to ensure that the barriers were based upon established theory and concepts. Then, questionnaire was pilot tested by school administrators, school teachers for its content and validity. Wherever necessary, questions are rephrased to improve its clarity and validity.

\subsection{Data Analysis}

The data collected from survey were analyzed in several ways. First, a frequency distribution generating absolute and cumulative frequencies and percentages is calculated for each question. Frequency is a statistic that tells as how many times a given score occurs in a collection of data. Frequency is therefore used to describe the demographic characteristics of the respondents. Percentile is also calculated from frequencies. Second, mean is calculated for the purpose of comparison of data with other questions. Third, factor analysis was used to reduce 10 barriers into 3 barrier factors. Lastly, Analysis of variance (ANOVA) was used to compare the differences in mean values of the constructs among teachers' personal characteristics (gender, age, annual income and designation) and teacher's ICT usage characteristics (computer proficiency, computer experience, ownership of computer/laptop, internet connection at home and time spent on computers/internet). Data is analyzed with the help of statistical software SPSS version 20.0.

\section{Results and Discussion}

\subsection{Descriptive Measures Associated with Barriers}

In order to evaluate the importance of teachers' perceived barriers to the use of ICT in secondary schools, mean values and standard deviation were calculated and are shown in Table 2. These include lack of funding (Mean =3.68), lack of ICT integration (Mean = 3.66), low connectivity $($ Mean= 3.65), power interruption $($ Mean $=3.64)$, inadequate maintenance of hardware and software (Mean =3.64), lack of skilled personnel (Mean =3.63), lack of confidence $($ Mean $=3.57)$, lack of motivation $($ Mean= 3.55), low awareness of ICT benefits $($ Mean $=3.54)$ and Poor ICT infrastructure $($ Mean $=3.54)$. These results are in some agreement with earlier research (Ihmeideh 2009, Nikolopoulou \& Gialamas 2013). 
Table 2. Descriptive Measures

\begin{tabular}{|l|c|c|}
\hline \multicolumn{1}{|c|}{ Barriers } & Mean & $\begin{array}{c}\text { Std. } \\
\text { Deviation }\end{array}$ \\
\hline Lack of funding & 3.68 & 1.064 \\
Lack of ICT integration & 3.66 & 1.149 \\
Low connectivity & 3.65 & 1.077 \\
Power interruption & 3.64 & 1.176 \\
Inadequate maintenance of hardware and software & 3.64 & 1.155 \\
Lack of skilled personnel & 3.63 & 1.082 \\
Lack of confidence & 3.57 & 1.178 \\
Lack of motivation & 3.55 & 1.145 \\
Low awareness of ICT benefits & 3.54 & 1.179 \\
Poor ICT infrastructure & 3.54 & 1.130 \\
& & \\
\hline
\end{tabular}

\subsection{Factor Analysis}

A factor analysis using 10 items of the barriers was conducted. Factor analysis resulted into three factors from the 10-items as shown in Table 3. The first factor (F1), labeled "lack of support", was associated with four items: lack of ICT integration, lack of adequate funding, inadequate maintenance of hardware and software, and power interruptions. The second factor (F2), labeled "lack of ICT infrastructure", was associated with three items: low connectivity, poor ICT infrastructure and lack of skilled personnel. The third factor (F3), labeled "lack of motivation and self belief", was associated with three items: lack of motivation, lack of confidence and low awareness of ICT benefits. After these factors were identified, a reliability test was done to examine each factor. All items within each factor were found to be reliable as shown in Table 3. These results are in agreement with the earlier study conducted by Al-Senaidi et al. (2009). Three of the factors extracted in our study, "lack of support", "lack of confidence" and "lack of equipment", were similar to the factors extracted in their study (conducted in higher education sector).

\subsection{Barrier Factors and Teacher's Personal Characteristics}

In order to know the Influence of teacher's personal characteristics on barrier factors, ANOVA was performed. ANOVA results in Table 4 shows that there was no significant difference in barrier factor "lack of support" based on the teacher's personal characteristics. Gender $(\mathrm{F}=2.895$ and $\mathrm{p}=0.89)$, age $(\mathrm{F}=1.226$ and $\mathrm{p}=0.294)$, designation $(\mathrm{F}=0.318$ and $\mathrm{p}$ $=0.728)$, and annual income $(\mathrm{F}=1.216$ and $\mathrm{p}=0.297)$ indicated no significant differences on lack of support. ANOVA results in Table 5 shows that there is no significant difference in barrier factor "lack of ICT infrastructure" based on the teacher's personal characteristics except annual income. Gender $(F=0.461$ and $p=0.497)$, age $(F=0.171$ and $p=0.843)$, and designation $(\mathrm{F}=0.067$ and $\mathrm{p}=0.935)$ indicated no significant differences on lack of ICT 


\section{Macrothink}

infrastructure. There is a significant difference in barrier factor "lack of ICT infrastructure" based on annual income $(F=3.781$ and $p=0.023)$. ANOVA results shown in Table 6 indicates that there is no significant difference in barrier factor "lack of motivation and self belief' based on the teacher's personal characteristics. Gender ( F 1.084 and $p=0.298)$, age $(\mathrm{F}=1.184$ and $\mathrm{p}=0.307)$, designation $(\mathrm{F}=0.229$ and $\mathrm{p}=0.795)$ and annual income $(\mathrm{F}=$ 0.538 and $\mathrm{p}=0.584$ ) indicated no significant differences on lack of motivation and self belief.

Table 3. Factor Matrix

\begin{tabular}{|l|c|c|c|}
\hline \multicolumn{1}{|c|}{ Barriers } & \multicolumn{3}{c|}{ Factor } \\
\cline { 2 - 4 } & 1 & 2 & 3 \\
\hline Inadequate maintenance of hardware and software & .775 & .322 & .319 \\
Power interruption & .654 & .277 & .266 \\
Lack of funding & .633 & .341 & .293 \\
Lack of ICT integration & .541 & .511 & .273 \\
Poor ICT infrastructure & .300 & .697 & .267 \\
Low connectivity & .405 & .594 & .286 \\
Lack of skilled personnel & .331 & .552 & .409 \\
Lack of confidence & .262 & .229 & .810 \\
Lack of motivation & .275 & .286 & .585 \\
Low awareness of ICT benefits & .356 & .406 & .509 \\
\hline Chronbach-alpha & .873 & .811 & .799 \\
Eigenvalues & 2.358 & 2.001 & 1.912 \\
Percentage of variance & 23.576 & 20.005 & 19.116 \\
\hline
\end{tabular}


Table 4. ANOVA Table Showing Relationships between Lack of Support and Teachers' Personal Characteristics

\begin{tabular}{|c|c|c|c|c|c|c|}
\hline & & $\begin{array}{c}\text { Sum of } \\
\text { Squares }\end{array}$ & $\mathrm{df}$ & $\begin{array}{l}\text { Mean } \\
\text { Square }\end{array}$ & $\mathrm{F}$ & Sig. \\
\hline Gender & $\begin{array}{l}\text { Between } \\
\text { Groups } \\
\text { Within } \\
\text { Groups } \\
\text { Total }\end{array}$ & $\begin{array}{r}2.095 \\
540.583 \\
542.678\end{array}$ & $\begin{array}{r}1 \\
747 \\
748\end{array}$ & $\begin{array}{r}2.095 \\
.724\end{array}$ & 2.895 & .089 \\
\hline Age & $\begin{array}{l}\text { Between } \\
\text { Groups } \\
\text { Within } \\
\text { Groups } \\
\text { Total }\end{array}$ & $\begin{array}{r}1.778 \\
540.900 \\
542.678\end{array}$ & $\begin{array}{r}2 \\
746 \\
748\end{array}$ & $\begin{array}{l}.889 \\
.725\end{array}$ & 1.226 & .294 \\
\hline Designation & $\begin{array}{l}\text { Between } \\
\text { Groups } \\
\text { Within } \\
\text { Groups } \\
\text { Total }\end{array}$ & $\begin{array}{r}.462 \\
542.216 \\
542.678\end{array}$ & $\begin{array}{r}2 \\
746 \\
748\end{array}$ & $\begin{array}{l}.231 \\
.727\end{array}$ & .318 & .728 \\
\hline $\begin{array}{l}\text { Annual } \\
\text { Income }\end{array}$ & $\begin{array}{l}\text { Between } \\
\text { Groups } \\
\text { Within } \\
\text { Groups } \\
\text { Total }\end{array}$ & $\begin{array}{r}1.763 \\
540.915 \\
542.678\end{array}$ & $\begin{array}{r}2 \\
746 \\
748\end{array}$ & $\begin{array}{l}.881 \\
.725\end{array}$ & 1.216 & .297 \\
\hline
\end{tabular}


Table 5. ANOVA Table Showing Relationships between Lack of ICT Infrastructure and Teachers' Personal Characteristics

\begin{tabular}{|c|c|c|c|c|c|c|}
\hline & & $\begin{array}{c}\text { Sum of } \\
\text { Squares }\end{array}$ & df & $\begin{array}{l}\text { Mean } \\
\text { Square }\end{array}$ & $\mathrm{F}$ & Sig. \\
\hline Gender & $\begin{array}{l}\text { Between } \\
\text { Groups } \\
\text { Within } \\
\text { Groups } \\
\text { Total }\end{array}$ & $\begin{array}{r}.290 \\
470.742 \\
471.033\end{array}$ & $\begin{array}{r}1 \\
747 \\
748\end{array}$ & $\begin{array}{l}.290 \\
.630\end{array}$ & .461 & .497 \\
\hline Age & $\begin{array}{l}\text { Between } \\
\text { Groups } \\
\text { Within } \\
\text { Groups } \\
\text { Total }\end{array}$ & $\begin{array}{r}.215 \\
470.818 \\
471.033\end{array}$ & $\begin{array}{r}2 \\
746 \\
748\end{array}$ & $\begin{array}{l}.108 \\
.631\end{array}$ & .171 & .843 \\
\hline Designation & $\begin{array}{l}\text { Between } \\
\text { Groups } \\
\text { Within } \\
\text { Groups } \\
\text { Total }\end{array}$ & $\begin{array}{r}.084 \\
470.948 \\
471.033\end{array}$ & $\begin{array}{r}2 \\
746 \\
748\end{array}$ & $\begin{array}{l}.042 \\
.631\end{array}$ & .067 & .935 \\
\hline $\begin{array}{l}\text { Annual } \\
\text { Income }\end{array}$ & $\begin{array}{l}\text { Between } \\
\text { Groups } \\
\text { Within } \\
\text { Groups } \\
\text { Total }\end{array}$ & $\begin{array}{r}4.726 \\
466.306 \\
471.033\end{array}$ & $\begin{array}{r}2 \\
746 \\
748\end{array}$ & $\begin{array}{r}2.363 \\
.625\end{array}$ & 3.781 & .023 \\
\hline
\end{tabular}


Table 6. ANOVA Table Showing Relationships between Lack of Motivation and Teachers' Personal Characteristics

\begin{tabular}{|c|c|c|c|c|c|c|}
\hline & & $\begin{array}{c}\text { Sum of } \\
\text { Squares }\end{array}$ & $\mathrm{df}$ & $\begin{array}{l}\text { Mean } \\
\text { Square }\end{array}$ & $\mathrm{F}$ & Sig. \\
\hline Gender & $\begin{array}{l}\text { Between } \\
\text { Groups } \\
\text { Within } \\
\text { Groups } \\
\text { Total }\end{array}$ & $\begin{array}{r}.784 \\
540.452 \\
541.236\end{array}$ & $\begin{array}{r}1 \\
747 \\
748\end{array}$ & $\begin{array}{l}.784 \\
.723\end{array}$ & 1.084 & .298 \\
\hline Age & $\begin{array}{l}\text { Between } \\
\text { Groups } \\
\text { Within } \\
\text { Groups } \\
\text { Total }\end{array}$ & $\begin{array}{r}1.712 \\
539.524 \\
541.236\end{array}$ & $\begin{array}{r}2 \\
746 \\
748\end{array}$ & $\begin{array}{l}.856 \\
.723\end{array}$ & 1.184 & .307 \\
\hline Designation & $\begin{array}{l}\text { Between } \\
\text { Groups } \\
\text { Within } \\
\text { Groups } \\
\text { Total }\end{array}$ & $\begin{array}{r}.332 \\
540.904 \\
541.236\end{array}$ & $\begin{array}{r}2 \\
746 \\
748\end{array}$ & $\begin{array}{l}.166 \\
.725\end{array}$ & .229 & .795 \\
\hline $\begin{array}{l}\text { Annual } \\
\text { Income }\end{array}$ & $\begin{array}{l}\text { Between } \\
\text { Groups } \\
\text { Within } \\
\text { Groups } \\
\text { Total }\end{array}$ & $\begin{array}{r}.779 \\
540.457 \\
541.236\end{array}$ & $\begin{array}{r}2 \\
746 \\
748\end{array}$ & $\begin{array}{l}.390 \\
.724\end{array}$ & .538 & .584 \\
\hline
\end{tabular}

\subsection{Barrier Factors and Teacher’s ICT Usage Characteristics}

Table 7 shows the data pertaining teachers ICT usage characteristics. In order to know the Influence of teacher's ICT usage characteristics on barrier factors, ANOVA was performed. ANOVA results shown in Table 8 indicates that there is a significant difference in barrier factor "lack of support" based on the teacher's ICT usage characteristics. Computer proficiency $(\mathrm{F}=10.415$ and $\mathrm{p}=0.001)$, ownership of computer/laptop $(\mathrm{F}=27.620$ and $\mathrm{p}=$ $0.00)$, internet connection at home $(\mathrm{F}=22.837$ and $\mathrm{p}=0.00)$ and time spent on computers/internet $(\mathrm{F}=6.882$ and $\mathrm{p}=0.001)$ indicated a significant differences on lack of support and computer experience $(\mathrm{F}=2.370$ and $\mathrm{p}=0.094)$ indicated no significant difference on lack of support. 
Table 7. Teacher's ICT Usage Characteristics

\begin{tabular}{|l|c|c|}
\hline & Frequency & Percentage (\%) \\
\hline Computer Proficiency & 624 & 83.3 \\
Yes & 125 & 16.7 \\
No & & \\
Computer Experience & 325 & 43.4 \\
$\quad<2$ years & 259 & 34.6 \\
$2-5$ years & 165 & 22.0 \\
$>5$ years & & 72.8 \\
Ownership of Computer/Laptop & 545 & 27.2 \\
Yes & 204 & 62.5 \\
No & 468 & 37.5 \\
Internet Connection at Home & 281 & \\
Yes & & 59 \\
No & & 25.5 \\
Time Spent on Computer/internet Per & 442 & 15.5 \\
Week & 191 & \\
$<2$ hours & 116 & \\
$2-5$ hours & & \\
$>5$ hours & & \\
\hline
\end{tabular}

ANOVA results shown in Table 9 indicates that there is a significant difference in barrier factor "lack of ICT infrastructure" based on the teacher's ICT usage characteristics. Computer proficiency $(\mathrm{F}=12.457$ and $\mathrm{p}=0.00)$, computer experience $(\mathrm{F}=3.104$ and $\mathrm{p}=$ $0.045)$, ownership of computer/laptop $(\mathrm{F}=21.452$ and $\mathrm{p}=0.00)$, internet connection at home $(\mathrm{F}=8.958$ and $\mathrm{p}=0.003)$ and time spent on computers/internet $(\mathrm{F}=8.759$ and $\mathrm{p}=0.00)$ indicated no significant differences on lack of ICT infrastructure. ANOVA results shown in Table 10 indicates that there is a significant difference in barrier factor "lack of motivation and self belief' based on the teacher's ICT usage characteristics. Computer proficiency ( $\mathrm{F}=$ 16.692 and $\mathrm{p}=0.00)$, ownership of computer/laptop $(\mathrm{F}=7.871$ and $\mathrm{p}=0.005)$, internet connection at home $(\mathrm{F}=8.161$ and $\mathrm{p}=0.004)$ and time spent on computers/internet $(\mathrm{F}=3.440$ and $\mathrm{p}=0.033$ ) indicated no significant differences on lack of motivation and self belief where as computer experience $(\mathrm{F}=1.838$ and $\mathrm{p}=0.160)$ indicated no significant difference on lack of motivation and self belief. 
Table 8. ANOVA Table Showing Relationships between Lack of Support and Teachers' ICT usage Characteristics

\begin{tabular}{|c|c|c|c|c|c|c|}
\hline & & $\begin{array}{l}\text { Sum of } \\
\text { Squares }\end{array}$ & $\mathrm{df}$ & $\begin{array}{l}\text { Mean } \\
\text { Square }\end{array}$ & $\mathrm{F}$ & Sig. \\
\hline $\begin{array}{l}\text { Computer } \\
\text { proficiency }\end{array}$ & $\begin{array}{l}\text { Between } \\
\text { Groups } \\
\text { Within Groups } \\
\text { Total }\end{array}$ & $\begin{array}{r}7.463 \\
535.216 \\
542.678\end{array}$ & $\begin{array}{r}1 \\
747 \\
748\end{array}$ & $\begin{array}{r}7.463 \\
.716\end{array}$ & 10.415 & .001 \\
\hline $\begin{array}{l}\text { Computer } \\
\text { experience }\end{array}$ & $\begin{array}{l}\text { Between } \\
\text { Groups } \\
\text { Within Groups } \\
\text { Total }\end{array}$ & $\begin{array}{r}3.427 \\
539.251 \\
542.678\end{array}$ & $\begin{array}{r}2 \\
746 \\
748\end{array}$ & $\begin{array}{r}1.713 \\
.723\end{array}$ & 2.370 & .094 \\
\hline $\begin{array}{l}\text { Ownership of } \\
\text { computer or } \\
\text { laptop }\end{array}$ & $\begin{array}{l}\text { Between } \\
\text { Groups } \\
\text { Within Groups } \\
\text { Total }\end{array}$ & $\begin{array}{r}19.350 \\
523.329 \\
542.678\end{array}$ & $\begin{array}{r}1 \\
747 \\
748\end{array}$ & $\begin{array}{r}19.350 \\
.701\end{array}$ & 27.620 & .000 \\
\hline $\begin{array}{l}\text { Internet } \\
\text { connection at } \\
\text { home }\end{array}$ & $\begin{array}{l}\text { Between } \\
\text { Groups } \\
\text { Within Groups } \\
\text { Total }\end{array}$ & $\begin{array}{r}16.100 \\
526.578 \\
542.678\end{array}$ & $\begin{array}{r}1 \\
747 \\
748\end{array}$ & $\begin{array}{r}16.100 \\
.705\end{array}$ & 22.839 & .000 \\
\hline $\begin{array}{l}\text { Time spent } \\
\text { on computers } \\
\text { or internet }\end{array}$ & $\begin{array}{l}\text { Between } \\
\text { Groups } \\
\text { Within Groups } \\
\text { Total }\end{array}$ & $\begin{array}{r}9.832 \\
532.846 \\
542.678\end{array}$ & $\begin{array}{r}2 \\
746 \\
748\end{array}$ & $\begin{array}{r}4.916 \\
.714\end{array}$ & 6.882 & .001 \\
\hline
\end{tabular}


Table 9. ANOVA Table Showing Relationships between Lack of ICT Infrastructure and Teachers' ICT usage Characteristics

\begin{tabular}{|c|c|c|c|c|c|c|}
\hline & & $\begin{array}{l}\text { Sum of } \\
\text { Squares }\end{array}$ & $\mathrm{df}$ & $\begin{array}{l}\text { Mean } \\
\text { Square }\end{array}$ & $\mathrm{F}$ & Sig. \\
\hline $\begin{array}{l}\text { Computer } \\
\text { proficiency }\end{array}$ & $\begin{array}{l}\text { Between } \\
\text { Groups } \\
\text { Within Groups } \\
\text { Total }\end{array}$ & $\begin{array}{r}7.726 \\
463.307 \\
471.033\end{array}$ & $\begin{array}{r}1 \\
747 \\
748\end{array}$ & $\begin{array}{r}7.726 \\
.620\end{array}$ & 12.457 & .000 \\
\hline $\begin{array}{l}\text { Computer } \\
\text { experience }\end{array}$ & $\begin{array}{l}\text { Between } \\
\text { Groups } \\
\text { Within Groups } \\
\text { Total }\end{array}$ & $\begin{array}{r}3.887 \\
467.146 \\
471.033\end{array}$ & $\begin{array}{r}2 \\
746 \\
748\end{array}$ & $\begin{array}{r}1.944 \\
.626\end{array}$ & 3.104 & .045 \\
\hline $\begin{array}{l}\text { Ownership of } \\
\text { computer or } \\
\text { laptop }\end{array}$ & $\begin{array}{l}\text { Between } \\
\text { Groups } \\
\text { Within Groups } \\
\text { Total }\end{array}$ & $\begin{array}{r}13.149 \\
457.884 \\
471.033\end{array}$ & $\begin{array}{r}1 \\
747 \\
748\end{array}$ & $\begin{array}{r}13.149 \\
.613\end{array}$ & 21.452 & .000 \\
\hline $\begin{array}{l}\text { Internet } \\
\text { connection at } \\
\text { home }\end{array}$ & $\begin{array}{l}\text { Between } \\
\text { Groups } \\
\text { Within Groups } \\
\text { Total }\end{array}$ & $\begin{array}{r}5.582 \\
465.451 \\
471.033\end{array}$ & $\begin{array}{r}1 \\
747 \\
748\end{array}$ & $\begin{array}{r}5.582 \\
.623\end{array}$ & 8.958 & .003 \\
\hline $\begin{array}{l}\text { Time spent on } \\
\text { computers or } \\
\text { internet }\end{array}$ & $\begin{array}{l}\text { Between } \\
\text { Groups } \\
\text { Within Groups } \\
\text { Total }\end{array}$ & $\begin{array}{r}10.807 \\
460.225 \\
471.033\end{array}$ & $\begin{array}{r}2 \\
746 \\
748\end{array}$ & $\begin{array}{r}5.404 \\
.617\end{array}$ & 8.759 & .000 \\
\hline
\end{tabular}


Table 10. ANOVA Table Showing Relationships between Lack of Motivation and Teachers' ICT usage Characteristics

\begin{tabular}{|c|c|c|c|c|c|c|}
\hline & & $\begin{array}{c}\text { Sum of } \\
\text { Squares }\end{array}$ & df & $\begin{array}{l}\text { Mean } \\
\text { Square }\end{array}$ & $\mathrm{F}$ & Sig. \\
\hline $\begin{array}{l}\text { Computer } \\
\text { proficiency }\end{array}$ & $\begin{array}{l}\text { Between } \\
\text { Groups } \\
\text { Within } \\
\text { Groups } \\
\text { Total }\end{array}$ & $\begin{array}{r}11.830 \\
529.407 \\
541.236\end{array}$ & $\begin{array}{r}1 \\
747 \\
748\end{array}$ & $\begin{array}{r}11.830 \\
.709\end{array}$ & 16.692 & .000 \\
\hline $\begin{array}{l}\text { Computer } \\
\text { experience }\end{array}$ & \begin{tabular}{|l} 
Between \\
Groups \\
Within \\
Groups \\
Total
\end{tabular} & $\begin{array}{r}2.654 \\
538.582 \\
541.236\end{array}$ & $\begin{array}{r}2 \\
746 \\
748\end{array}$ & $\begin{array}{r}1.327 \\
.722\end{array}$ & 1.838 & .160 \\
\hline $\begin{array}{l}\text { Ownership of } \\
\text { computer or } \\
\text { laptop }\end{array}$ & $\begin{array}{l}\text { Between } \\
\text { Groups } \\
\text { Within } \\
\text { Groups } \\
\text { Total }\end{array}$ & $\begin{array}{r}5.644 \\
535.593 \\
541.236\end{array}$ & $\begin{array}{r}1 \\
747 \\
748\end{array}$ & $\begin{array}{r}5.644 \\
.717\end{array}$ & 7.871 & .005 \\
\hline $\begin{array}{l}\text { Internet } \\
\text { connection at } \\
\text { home }\end{array}$ & \begin{tabular}{|l} 
Between \\
Groups \\
Within \\
Groups \\
Total
\end{tabular} & $\begin{array}{r}5.849 \\
535.387 \\
541.236\end{array}$ & $\begin{array}{r}1 \\
747 \\
748\end{array}$ & $\begin{array}{r}5.849 \\
.717\end{array}$ & 8.161 & .004 \\
\hline $\begin{array}{l}\text { Time spent } \\
\text { on computers } \\
\text { or internet }\end{array}$ & \begin{tabular}{|l} 
Between \\
Groups \\
Within \\
Groups \\
Total
\end{tabular} & $\begin{array}{r}4.947 \\
536.290 \\
541.236\end{array}$ & $\begin{array}{r}2 \\
746 \\
748\end{array}$ & $\begin{array}{r}2.473 \\
.719\end{array}$ & 3.440 & .033 \\
\hline
\end{tabular}

Results from the study shows that lack of funding, lack of ICT integration and lack of connectivity were found to be most critical barriers to the adoption of ICT in secondary schools. Teachers' usage characteristics such as proficiency in computers, computer experience, time spent on computers, internet connection at home and ownership of computers had influence on barrier factors.

\section{Conclusion}

This study focused on understanding the barrier factors that affect the usage of ICT in secondary schools and as such has limited generalizability. Findings from the paper provide deep insights into the factors that are hindering the usage of ICT in a broader range of 
teaching and learning environments. It is recommended that government and school management should aware the significance of ICT in learning and teaching and should overcome the barriers that hinders ICT usage among teachers and students. All educational sectors need to be conscious of the possibilities and significance of ICT in developing student's learning in order to prevail over the barriers which prevent technology use in secondary schools, so that students can benefit effectively from computer use. In parallel with in-service teacher training, technical, financial and administrative support is needed for secondary schools. Within the broader area of ICT, there is a general recognition for the need of professional development and support to integrate ICT efficiently and effectively (Van Melle et al. 2003; Pelgrum 2001). Teachers' perceived barriers can be further explored with larger and more diverse samples. Additionally, this study could be enriched by using a mixed method (e.g., qualitative and quantitative approaches) in order to obtain a better understanding of the situation. When teachers respond to closed survey items, only the issues questioned can be identified. While open-ended questions may reveal, for example, how some previously reported barriers have changed and may help in understanding the importance of barriers while integrating ICT in learning and teaching.

Future research is required on how these barriers can be overcome to sustain effective use of ICT in secondary schools. The fast advancements in ICT make it not easy to assess the impact of potential barriers over time (Wood et al. 2005). Further research is suggested to investigate (i) how secondary school teachers' perceptions of technology barriers transform over time and (ii) the link between teachers' perceptions and their teaching and learning practices.

\section{Acknowledgement}

The research is financed by BITS Pilani as part of SEED GRANT PROJECT. Thanks to Vice Chancellor Prof. B.N. Jain, Director Prof. K.E Raman and Prof. R. N Saha for sponsoring this project.

\section{References}

Agyei, D., \& Voogt, J. (2011). ICT use in the teaching of mathematics: implications for professional development of pre-service teachers in Ghana. Education and Information Technologies, 16(4), 423-439. http://dx.doi.org/10.1007/s10639-010-9141-9

Al-Senaidi, S., Lin, L., \& Poirot, J. (2009). Barriers to adopting technology for teaching and learning in Oman. Computers \& Education, 53(3), 575-590. http://dx.doi.org/10.1016/j.compedu.2009.03.015

Bichelmeyer, B., \& Molenda, M. (2006). Issues and trends in instructional technology: Gradual growth atop tectonic shifts. In M. Orey, J. McClendon, \& R. M. Branch (Eds.), Educational media and technology yearbook, 31, 3-32.

Bingimlas, K. (2009). Barriers to the successful integration of ICT in teaching and learning environments: a review of the literature. Eurasia Journal of Mathematics, Science \& Technology Education, 5(3), 235-245. 
Butler, D. L., \& Sellbom, M. (2002). Barriers to adopting technology for teaching and learning. EDUCAUSE Quarterly, 25(2), 22-28.

Castellani, J., \& Jeffs, T. (2001). Emerging reading and writing strategies using technology. Teaching Exceptional Children, 33(5), 60-67.

ChanLin, L.J., Hong, J.C., Horng, J.S., Chang, S.H., \& Chu, H.C. (2006). Factors influencing technology integration in teaching: A Taiwanese perspective. Innovations in Education and Teaching International, 43(1), 57-68. http://dx.doi.org/10.1080/14703290500467467

Copley, J., \& Ziviani, J. (2004). Barriers to the use of assistive technology for children with multiple disabilities. Occupational Therapy International, 11(4), 229-243. http://dx.doi.org/10.1002/oti.213

Ertmer P. A. (1999). Addressing first- and second-order barriers to change: strategies for technology integration. Educational Technology Research and Development, 47, 47-61. http://dx.doi.org/10.1007/BF02299597

Galanouli, D., Murphy, C. \& Gardner, J. (2004). Teachers' perceptions of the effectiveness of ICT-competence training. Computers \& Education, 43, 63-79. http://dx.doi.org/10.1016/j.compedu.2003.12.005

Georgina, D. A., \& Hosford, C. C. (2009). Higher education faculty perceptions on technology integration and training. Teaching and Teacher Education, 25(5), 690-696. http://dx.doi.org/10.1016/j.tate.2008.11.004

Groves, M. M., \& Zemel, P. C. (2000). Instructional technology adoption in higher education: An action research case study. International Journal of Instructional Media, 27(1), 57-65.

Han, W. (2008). Benefits and barriers of computer assisted language learning and teaching. US-China Foreign Language, 6(9), 40-43.

Ihmeideh, F.M. (2009). Barriers to the use of technology in Jordanian pre - school settings. Technology, Pedagogy and Education, 18(3), 325-341. http://dx.doi.org/10.1080/14759390903255619

Ilomäki, L. (2011). Does Gender Have a Role in ICT among Finnish Teachers and Students?. Scandinavian Journal of Educational Research, 55(3), 325-340. http://dx.doi.org/10.1080/00313831.2011.576910

Jones, A. (2004). A review of the research literature on barriers to the uptake of ICT by teachers. Coventry: British Educational Communications and Technology Agency.

Karasavvidis, I. (2009). Activity theory as a conceptual framework for understanding teacher approaches to information and communication technologies. Computers \& Education, 53(2), 436-444. http://dx.doi.org/10.1016/j.compedu.2009.03.003

Lim, C. P., \& Khine, M. (2006). Managing teachers' barriers to ICT integration in Singapore schools. Journal of Technology and Teacher Education, 14(1), 97-125. 
Lo“ fstro“ m, E., \& Nevgi, A. (2008). University teaching staffs' pedagogical awareness displayed through ICT-facilitated teaching. Interactive Learning Environments, 16(2), 101-116.

McCarney, J. (2004). Effective models of staff development in ICT. European Journal of Teacher Education, 27(1), 61-72. http://dx.doi.org/10.1080/0261976042000211801

Neyland, E. (2011). Integrating online learning in NSW secondary schools: Three schools' perspectives on ICT adoption. Australasian Journal of Educational Technology, 27(1), $152-173$.

Nikolopoulou, K., \& Gialamas, V. (2013). Barriers to the integration of computers in early childhood settings: Teachers' perceptions. Educ Inf Technol. http://dx.doi.org/10.1007/s10639-013-9281-9

Oye , N. D., Salleh, M., \& Iahad, N. A. (2011). Challenges of E-learning in Nigerian University Education Based on the Experience of Developed Countries. International Journal of Managing Information Technology, 3(2), 39-48. http://dx.doi.org/10.5121/ijmit.2011.3204

Pelgrum, W. J. (2001). Obstacles to the Integration of ICT in Education: Results from a Worldwide Educational Assessment. Computers and Education, 37, 163-78. http://dx.doi.org/10.1016/S0360-1315(01)00045-8

Pliskin, N., T. Romm, A.S. Lee, \& Y. Weber (1993). Presumed versus Actual Organisational Culture: Managerial Implications for Implementation of Information Systems. The Computer Journal, 36(2), 1-10. http://dx.doi.org/10.1093/comjnl/36.2.143

Prestridge, S. (2012). The beliefs behind the teacher that influences their ICT practices. Computers \& Education, 58(1), 449-458. http://dx.doi.org/10.1016/j.compedu.2011.08.028

Richardson, J. W. (2011) Challenges of Adopting the Use of Technology in Less Developed Countries: The Case of Cambodia. Comparative Education Review, 55(1), 008-029.

Rodrigo, M. M. T. (2005). Quantifying the Divide: A Comparison of ICT Usage of Schools in Metro Manila and IEA-Surveyed Countries. International Journal of Educational Development, 25(1), 53-68. http://dx.doi.org/10.1016/j.ijedudev.2004.07.002

Salehi, H., \& Salehi, Z. (2012). Challenges for Using ICT in Education: Teachers' Insights. International Journal of e-Education, e-Business, e-Management and e-Learning, 2(1), 40-43.

Van Melle, E., Cimellaro, L., \& Shulha, L. (2003). A dynamic framework to guide the implementation and evaluation of educational technologies. Education and Information Technologies, 8(3), 267-285. http://dx.doi.org/10.1023/A:1026312110143

Veen, W. (1993). The role of beliefs in the use of information technology: implications for teacher education, or teaching the right thing at the right time. Journal of Information Technology for Teacher Education, 2, 139-153. http://dx.doi.org/10.1080/0962029930020203 


\section{Macrothink}

Journal of Management Research

ISSN 1941-899X 2015, Vol. 7, No. 2

Wood, E., Mueller, J., Willoughby, T., Specht, J., \& Deyoung, T. (2005). Teachers' perceptions: barriers and supports to using technology in the classroom. Education, Communication and Information, 5(2), 183-206. http://dx.doi.org/10.1080/14636310500186214

Yunus, M. M., Lubis, M., \& Lin, C. (2009). Language Learning via ICT: Uses, Challenges and Issues. WSEAS Transactions on Information Science and Applications, 6(9), 1453-1467.

\section{Copyright Disclaimer}

Copyright for this article is retained by the author(s), with first publication rights granted to the journal.

This is an open-access article distributed under the terms and conditions of the Creative Commons Attribution license (http://creativecommons.org/licenses/by/3.0/). 